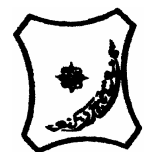

Bayero Journal of Pure and Applied Sciences, 9(2): 148 - 153

Received: August, 2016

Accepted: August, 2016

ISSN $2006-6996$

\title{
INFLUENCE OF WEED CONTROL METHODS, POULTRY MANURE AND PLANTING PATTERN ON GROWTH AND YIELD ATTRIBUTES OF MAIZE (Zea mays L.) IN THE NORTHERN GUINEA SAVANNAH ZONE OF NIGERIA
}

\author{
Bature, M.S., ${ }^{1}$ Ishaya, D.B., ${ }^{2}$ Mahadi, M.A ${ }^{2}$, Sharifai, A.I ${ }^{2}$; Muhammed, A.A ${ }^{2}$; Hassan, A. $\mathbf{H}^{1}$; \\ Jibril, H.J; Goma, $\mathrm{L}^{2}$ and Munir, G.M ${ }^{3}$ \\ ${ }^{1}$ College of Agriculture and Animal Science, Ahmadu Bello University, Mando-Kaduna \\ ${ }^{2}$ Department of Agronomy, Faculty of Agriculture, Institute for Agricultural Research, Ahmadu Bello University, Zaria \\ -Nigeria \\ ${ }^{3}$ Department of Agricultural Education, Federal College of Education, Kano \\ Corresponding author email: salisumusabature@gmail.com GSM NO: 08065549941 or 08170059778
}

\begin{abstract}
Field trials were conducted during the rainy seasons (2012 and 2013) at the Research Farm of Institute for Agricultural Research, Samaru Zaria and College of Agriculture and Animal Science, Mando Kaduna, in the Northern Guinea Savannah Zone of Nigeria, to determine the Influence of weed control methods, poultry manure and planting pattern on the performance of maize (Zea mays L.). The treatments consisted of six levels of weed control (S-metolachlor + atrazine at 1.98 and $2.64 \mathrm{~kg}$ a.i/ha, butachlor at 1.5 and $2.5 \mathrm{~kg}$ a.i/ha, hoe weeding at 3 and 6 weeks after sowing (WAS) and a weedy check), three levels of poultry manure (0, 4 and 8 t/ha) and two planting pattern (single and double row per ridge). The treatments were laid out in spit-plot design replicated three times. Weed control and poultry manure were assigned to the main plots, while planting pattern was assigned in the sub-plots. Results from the study showed that application of S-metolachlor + atrazine at $2.64 \mathrm{~kg}$ a.i/ha, butachlor at $2.5 \mathrm{~kg}$ a.i/ha and hoe weeding at 3 and 6 WAS produced taller maize plants, increase in relative growth rate and higher grain yield. However, application of poultry manure at $8 t / h a$ gave the tallest maize plants, increase in relative growth rate and higher total grain yield, while double planting pattern (double row per ridge) suppressed weed population and ensured better crop performance and higher grain yield compared to the single planting pattern (single row per ridge).
\end{abstract} Key words: weed control, planting pattern, poultry manure

\section{INTRODUCTION}

Maize (Zea mays L.) is the world's third most important crop after rice and wheat. It is grown in developing countries and is the most commonly grown cereal in Nigeria, with an annual production of 11.3 million metric tons. It is widely cultivated throughout the world and a greater quantity is produced each year than any other grain (FAO, 2014). According to Food and Agriculture Organization (FAO, 2014), maize yields currently average $1.5 \mathrm{t} / \mathrm{ha}$ in Africa, slightly more than 3 $\mathrm{t} /$ ha in Latin America, and $1.7 \mathrm{t} / \mathrm{ha}$ in India. Brazil currently stands out as one of the largest maize producers in the world, with an estimated production of 79,000 tons in the $2013 / 2014$ harvest. A total of 826.2 million metric tons of maize were produced worldwide (FAO, 2014).

Maize is used as a major food crop, livestock feed and as a raw materials for industrial products e.g in Australia as feed, silage breakfast food and processing (breakfast cereals, corn, chips, grits and flour), industrial starch and popcorn. In Sub- Saharan Africa, maize is a staple food for estimated $50 \%$ of the population and provides $50 \%$ of the basic calories. It is an important source of carbohydrate, protein, iron, vitamin B, and minerals, past grits and beer. Green maize (fresh on the cob is eaten parched, baked, roasted or boiled and plays an important role in filling the hunger gab after the dry season (Stinger et al., 2015b). Thus maize more than any crop, offers the promise of meeting Africa's food need in this millennium (Idem and Showemimo, 2014).

Maize production in Nigeria is seriously constrained by weed infestation. Weeds affect maize by competing for nutrients, light, water and space. Weeds harbor insect pests that damage the crop (Ogundele, 2006). The estimated losses due to uncontrolled weeds are about $80 \%$ of the potential grain yield of maize (Lagoke et al., 1986). Also, Anikwe et al. (2000) reported that total crop failure may occur in maize crop if weeds are not controlled. These workers also observed that keeping maize crop weed free for 60 days after sowing increased grain yield by $60 \%$ compared to the weedy check. Weed interference not only results in crop losses, but also generally conceded that the current economic damage to agriculture from weeds far surpasses the more incidental damage inflicted by insect pest, rodents and diseases (Oudejans, 1991).

On the other hand, use of chemical fertilizer has not provided adequate measures in maintenance of soil fertility for sustaining the productivity (Sharma and Mitra, 1991, Yahaya, 1993). Nitrogen increases maize production in the Guinea Savannah Ecological Zone of Nigeria (Singh et al., 2001, EL-Gizawy and Saleem 2010 and Sharifai, 2011). The use of chemical fertilizers to supplement nitrogen source is appreciated by farmers but high cost of fertilizer, poor distribution, adulteration, low subsidy, scarce financial resource and in adequate credit facilities made the commodity not easily accessible. 
There is, therefore, the need to seek for alternative to inorganic fertilizer. Poultry manure may serve as a renewable source of nitrogen. Hence it can be a good alternative to reduce these problems. There is also serious health problem in the use of chemical fertilizer, diminishing food quality due to chemical deposit in crop fruits and seeds. Sharma (2001) also stated that the use of poultry manure is capable of solving the mentioned limitations because of its ability to improve physical, chemical and biological properties of soil.

Furthermore, maize is cultivated in rows, however, recently there has been an interest of different planting pattern, such as double and single pattern row per ridge. Several reports revealed that double planting pattern produced higher grain yield than the single planting pattern (Sener, et al ., 2004 and Sarlangue, et al., 2007). Maize is widely grown in savanna ecological zone, but farmers do not adhere to planting pattern. Saberali (2007) reported that double planting pattern (double row per ridge) increased leaf area index, total dry matter and crop growth rate compare to single planting. Single planting pattern (single row per ridge) increased the incidence of weed competition (Munamara, et al., 2006; Gozubenli, 2010). It is, therefore recommended for farmers to adhere to double planting pattern, than the conventional pattern which may suppress weeds, thereby reducing competition and increasing maize yield. Cox et al. (2006) stated that double planting pattern had greater corn silage dry matter than the single planting pattern. Hashemi, et al. (2005) reported that double planting pattern produced more yield than the single planting pattern.

The study was therefore conceived with the objective of determining the influence of weed control methods, poultry manure rates and planting pattern on weed infestation on the performance of maize (Zea mays L.) in the Northern Guinea Savanna Zone of Nigeria.

\section{MATERIALS AND METHODS}

Field trials were conducted during the rainy seasons of 2012 and 2013 at the Research Farm of the Institute for Agricultural Research, Samaru $\left(11^{0} 11^{1} \mathrm{~N}, 0.7^{0} 38^{0} \mathrm{E}\right.$ and 686 meters above sea level) and College of Agriculture and Animal Science, Mando Kaduna, $\left(7.43^{\circ} \mathrm{N} 8.33^{\prime} \mathrm{E}\right.$ of the equator and 632 meters above sea level) in the Northern guinea savanna zone of Nigeria. The treatments consisted of six levels of weed control (Smetolachlor + atrazine at 1.89 and $2.64 \mathrm{~kg}$ a.i/ha, butachlor at 1.5 and $2.5 \mathrm{~kg}$ a.i/ha, two hoe weeding at 3 and 6 weeks after sowing (WAS) and a weedy check). Three levels of poultry manure $(0,4$ and $8 \mathrm{t} / \mathrm{ha})$ and two planting pattern (single and double row per ridge). The treatments were laid out in a split plot design and replicated three times. The weed control treatments and poultry manure were assigned to the main plots while planting pattern was assigned to the sub-plots. The gross and net plot area sizes were $18 \mathrm{~m}^{2}$ and $12 \mathrm{~m}^{2}$ respectively. Composite soil samples were also collected for their physic and chemical properties in each year, with an auger of $10 \mathrm{~cm}$ diameter at the depth of $0-30 \mathrm{~cm}$ in which the samples were air dried and sieved using standard procedure as described by (Black, 1968). Poultry manure used during the trials at both Samaru and Mando in the 2012 and 2013, were sourced from layers dropping. Dried samples of the poultry manure were grinded and analysed for $\mathrm{N}, \mathrm{P}$ and $\mathrm{K}$. The total nitrogen was determined by Micro-kjeldahl method (Bremmer, 1965). Available phosphorous was analyzed according to Bray's method described by Olsen et al., (1986). Poultry manure was applied manually by spreading and incorporation into the soil on treatment basis, two weeks prior to sowing. Data on rainfall distribution, temperature, sunshine and relative humidity for the 2012 and 2013 raining seasons were collected at Samaru Meteorological Unit of Institute for Agricultural Research Station and at Meteorological Unit of National Airport Research Station (Nimet, Kaduna). The experimental sites were ploughed, harrowed to a fine tilth at both locations, in both years and ridged $75 \mathrm{~cm}$ apart with a tractor. The sites were marked out into 108 plots with three (3) replications. An alley way of one meter across and one ridge along the plots were used as borders between the plots, while replications were separated by two ridges. The gross plot and net plot sizes was $18 \mathrm{~m}^{2}$ and $12 \mathrm{~m}^{2}$ respectively. The maize variety used in the trial was SAMMAZ 37. It is a medium maturing variety and can attain a height of about $170 \mathrm{~cm}$ and tolerant to Striga hermonthica. It is resistant to maize streak virus and also drought tolerant. The seeds are yellow in color and have a yield potential of about $4.5 \mathrm{t} / \mathrm{ha}$. The seeds were sown manually at the rate of two seed per hole along the ridges, using an intra row spacing of $25 \mathrm{~cm}$ and later were thinned to one plant per stand at 2 weeks after sowing. The herbicides were applied on treatment basis using a CP3 knapsack sprayer fitted with a green deflector polyjet nozzle and set at a pressure of $2.1 \mathrm{~kg} / \mathrm{m}^{2}$ that gave a spray volume of $250 \mathrm{l} / \mathrm{ha}$. Hoe weeding was carried out at 3 and 6 weeks after sowing (WAS) for the hoe weeding treatment at both sites and years of the experiment. The crop was harvested as the plants attained physiological maturity. The ears from the net plots were removed manually and de-husked. The cobs were sun dried and later shelled and winnowed in the air to obtain clean grains. Data collected was subjected to statistical analysis of variance (ANOVA) using general linear model GLM of the Statistical Analysis System package (SAS, 2003). The treatment means were separated using Duncan's multiple range test (Duncan, 1955).

\section{RESULTS}

Influence of weed control, poultry manure and planting pattern on plant height of maize at 9 weeks after sowing

The influence of weed control, poultry manure and planting pattern on plant height of maize at 9 WAS is presented in (Table 1). Results showed that control of weeds with hoe weeding at 3 and 6 WAS, gave significantly taller plants, than all the herbicides and the weed check at both locations in all the years and their mean. Among the herbicides that were evaluated, application of higher rate of S-metolachlor + atrazine at $2.64 \mathrm{~kg} \mathrm{a.i} / \mathrm{ha}$ at Samaru and Mando in 2012 and butachlor at $2.5 \mathrm{~kg}$ a.i/ha at Mando in 2012 recorded tallest maize plants, than all the other rates of herbicides at both locations and in both years (Table 1). 
Significantly taller maize plants was obtained with 8 t/ha of poultry manure was obtained at both locations, and in both years, which was similar with 4 t/ha of poultry manure at Samaru in 2013 and at Mando also in 2013, than with application of $4 \mathrm{t} / \mathrm{ha}$ of poultry manure at both locations in 2012 and mean. While shortest maize plants were recorded with non application of poultry manure throughout the locations, years and the means (Table 1 ).

The results further revealed that planting pattern with both the single and double pattern was not significant at both locations, in all years and their means, but higher mean values were recorded in the double planting pattern at Samaru in 2012 and mean.

Influence of weed control, poultry manure and planting pattern on relative growth rate of maize at 9 weeks after sowing

Table 2 showed that weed control treatments, poultry manure and planting pattern during the sampling period of 9 WAS on relative growth rate of maize was significant throughout the locations, years and the means. Influence of weed control treatments significantly recorded the highest increase on relative growth rate of maize with hoe weeding at 3 and 6 WAS throughout the locations, years and the means, which was statistically similar with application of higher rate $(2.5 \mathrm{~kg}$ a.i $/ \mathrm{ha})$ of butachlor at both Samaru and Mando in 2012, than all other herbicides and the weedy check (Table 2 ).

Influence of poultry manure application gave higher increase in relative growth rate with application of 8 t/ha of poultry manure, than with application of 4 t/ha, while lower relative growth rate was obtained with the control, at both locations, years and their means.

Planting pattern at both locations in all years and means was however not significant, with both the single and double planting pattern on the relative growth rate, but higher mean values was obtained at Samaru in 2012 and at Mando in both years and mean (Table 2).

Influence of weed control, poultry manure and planting pattern on total grain yield of maize

Weed control, poultry manure and planting pattern had significantly influence total grain yield of maize in all the locations and years as presented in (Table 3 ). Weed control treatments with hoe weeding at 3 and 6 WAS, recorded the highest grain yield of maize in both locations, years and the means, which was similar with application of S-metolachlor + atrazine at $2.64 \mathrm{~kg} \mathrm{a.i} / \mathrm{ha}$ at Samaru in 2012 and at Mando in both years, butachlor at $2.5 \mathrm{~kg}$ a.i/ha at Samaru in 2012 and also with butachlor at 1.5 and $2.5 \mathrm{~kg}$ a.i/ha at Mando in 2012, than with other herbicides and the weedy check (Table 3 ).

Poultry manure application, in all the locations, years and means gave highest grain yield with $8 \mathrm{t} /$ ha of poultry manure application, being higher than with application of $4 \mathrm{t} / \mathrm{ha}$ of poultry manure, but less grain weight was obtained with non application of poultry manure, at both locations, years and the means.

Influence of planting pattern on grain yield recorded significantly highest grain yield of maize with double planting pattern compared to the single planting pattern across the locations, years and the mean (Table 3)

Table 1: Influence of weed control methods, poultry manure and planting pattern on plant height $(\mathrm{cm})$ of maize (Zea mays L.) at 9 WAS at Samaru and Mando during 2012 and 2013 rainy seasons

\begin{tabular}{|c|c|c|c|c|c|c|c|}
\hline \multirow[t]{2}{*}{ Treatment } & \multirow{2}{*}{$\begin{array}{l}\text { Rate In } \\
\mathrm{kg} \mathrm{a.i/ha}\end{array}$} & \multicolumn{3}{|c|}{ Samaru } & \multicolumn{3}{|c|}{ Mando } \\
\hline & & 2012 & 2013 & Mean & 2012 & 2013 & Mean \\
\hline \multicolumn{8}{|l|}{ Weed Control } \\
\hline S- met + atra & 1.98 & $91.52 \mathrm{c}$ & $97.93 b c$ & $94.73 c$ & $103.50 c$ & $102.94 b$ & $103.22 \mathrm{c}$ \\
\hline S- met + atra & 2.64 & 98.03ab & $100.21 \mathrm{~b}$ & $99.12 \mathrm{~b}$ & $110.84 a b$ & $103.75 b$ & $107.30 \mathrm{~b}$ \\
\hline Butachlor & 1.5 & $93.84 b c$ & $94.92 b c$ & $94.16 c$ & $108.96 b c$ & $104.32 b$ & $106.64 \mathrm{bc}$ \\
\hline Butachlor & 2.5 & $97.14 b$ & $97.92 b c$ & $97.53 b c$ & $112.11 a b$ & $105.66 \mathrm{~b}$ & $108.88 \mathrm{~b}$ \\
\hline Hoe Weeding & $3 \& 6$ WAS & 102.98a & $105.86 a$ & $104.42 \mathrm{a}$ & $116.26 a$ & $110.96 a$ & $113.61 \mathrm{a}$ \\
\hline Weedy Check & & $63.14 d$ & $72.58 \mathrm{~d}$ & $67.86 \mathrm{~d}$ & $76.72 d$ & $73.94 \mathrm{C}$ & $75.33 d$ \\
\hline S.E \pm & & 4.900 & 4.362 & 3.512 & 6.110 & 0.052 & 3.522 \\
\hline Poultry Manure & (tons/ha) & & & & & & \\
\hline 0 & & $64.79 c$ & $70.71 \mathrm{c}$ & $67.75 c$ & $72.21 \mathrm{c}$ & $74.89 c$ & $73.55 c$ \\
\hline 4 & & $87.89 \mathrm{~b}$ & $110.84 a b$ & $89.21 b$ & $102.88 \mathrm{~b}$ & $112.23 a b$ & $98.56 \mathrm{~b}$ \\
\hline 8 & & $120.99 a$ & $122.95 a$ & $121.95 a$ & 139.11a & $131.66 a$ & $135.39 a$ \\
\hline $\begin{array}{l}\text { S.E } \pm \\
\text { Planting Pattern }\end{array}$ & \multicolumn{4}{|c|}{ Planting Pattern } & 4.320 & 2.162 & 2.490 \\
\hline Single & & 90.08 & 94.82 & 92.46 & 104.61 & 100.19 & 102.40 \\
\hline Double & & 92.14 & 94.84 & 93.49 & 104.86 & 100.34 & 102.60 \\
\hline S.E \pm & & 2.121 & 0.372 & 1.082 & 0.990 & 0.532 & 0.560 \\
\hline Interaction & & & & & & & \\
\hline$W * P M$ & & NS & NS & NS & NS & NS & NS \\
\hline $\mathrm{W} * \mathrm{PP}$ & & NS & NS & NS & NS & NS & NS \\
\hline P M* PP & & NS & NS & NS & NS & NS & NS \\
\hline $\mathrm{W} * \mathrm{PM} * \mathrm{PP}$ & & NS & NS & NS & NS & NS & NS \\
\hline
\end{tabular}


BAJOPAS Volume 9 Number 2 December, 2016

Table 2: Influence of weed control methods, poultry manure and planting pattern on relative growth rate of maize (Zea mays L.) ( $\left.\mathrm{g} \mathrm{g}^{-1} \mathrm{wk}^{-1}\right)$ at 9 WAS, at Samaru and Mando during 2012 and 2013 rainy seasons

\begin{tabular}{|c|c|c|c|c|c|c|c|}
\hline \multirow{3}{*}{ Treatment } & \multicolumn{7}{|l|}{ Rate } \\
\hline & In & \multicolumn{3}{|c|}{ Samaru } & \multicolumn{3}{|c|}{ Mando } \\
\hline & $\mathrm{kg}$ a.i/ha & 2012 & 2013 & Mean & 2012 & 2013 & Mean \\
\hline \multicolumn{8}{|l|}{ Weed Control } \\
\hline$\overline{s-\text { met + atra }}$ & 1.98 & $0.261 b$ & $0.311 \mathrm{c}$ & $0.286 c$ & $0.325 c$ & $0.350 \mathrm{~b}$ & $0.338 c$ \\
\hline $\mathrm{S}-$ met + atra & 2.64 & $0.263 b$ & $0.320 b c$ & $0.291 b c$ & $0.334 b c$ & $0.359 b$ & $0.347 b c$ \\
\hline Butachlor & 1.5 & $0.265 b$ & $0.311 \mathrm{c}$ & $0.288 c$ & $0.350 \mathrm{bc}$ & $0.353 b$ & $0.352 b c$ \\
\hline Butachlor & 2.5 & $0.282 \mathrm{ab}$ & $0.328 \mathrm{~b}$ & $0.308 b$ & $0.354 a b$ & $0.363 b$ & $0.359 b$ \\
\hline Hoe Weeding & $3 \& 6$ WAS & $0.296 a$ & $0.346 a$ & $0.321 a$ & $0.377 a$ & $0.401 a$ & $0.390 a$ \\
\hline Weedy Check & & $0.178 \mathrm{c}$ & $0.226 \mathrm{~d}$ & $0.202 d$ & $0.219 \mathrm{~d}$ & $0.230 \mathrm{c}$ & $0.225 d$ \\
\hline S.E \pm & & 0.001 & 0.011 & 0.004 & 0.041 & 0.001 & 0.002 \\
\hline \multicolumn{8}{|l|}{ Poultry Manure } \\
\hline$\overline{0}$ & & $0.20 \mathrm{c}$ & $0.246 c$ & $0.223 c$ & $0.288 c$ & $0.309 c$ & $0.299 c$ \\
\hline 4 & & $0.27 b$ & $0.315 b$ & $0.292 b$ & $0.326 b$ & $0.339 b$ & $0.333 b$ \\
\hline 8 & & $0.30 a$ & $0.360 \mathrm{a}$ & $0.331 \mathrm{a}$ & $0.366 a$ & $0.380 \mathrm{a}$ & $0.373 a$ \\
\hline S.E \pm & & 0.001 & 0.009 & 0.006 & 0.005 & 0.009 & 0.001 \\
\hline \multicolumn{8}{|l|}{ Planting Pattern } \\
\hline Single & & 0.256 & 0.307 & 0.281 & 0.327 & 0.343 & 0.335 \\
\hline Double & & 0.259 & 0.307 & 0.283 & 0.326 & 0.343 & 0.335 \\
\hline S.Et & & 0.003 & 0.006 & 0.001 & 0.009 & 0.006 & 0.004 \\
\hline \multicolumn{8}{|l|}{ Interaction } \\
\hline W*PM & & NS & NS & NS & NS & NS & NS \\
\hline $\mathrm{W} * \mathrm{PP}$ & & NS & NS & NS & NS & NS & NS \\
\hline $\mathrm{P} M * P P$ & & NS & NS & NS & NS & NS & NS \\
\hline $\mathrm{W} * \mathrm{PM} * \mathrm{PP}$ & & NS & NS & NS & NS & NS & NS \\
\hline
\end{tabular}

Means within a column of any set of treatment group with unlike letter(s) are significantly different at $\mathrm{P} \leq 0.05$ using DMRT

Table 3: Influence of Weed Control methods, Poultry Manure and Planting Pattern on the Performance of maize (Zea mays L.) on total grain yield of maize $(\mathrm{kg})$ at Samaru and Mando during 2012 and 2013 rainy seasons

\begin{tabular}{|c|c|c|c|c|c|c|c|}
\hline \multirow[t]{2}{*}{ Treatment } & \multirow{2}{*}{$\begin{array}{r}\text { Rates } \\
\mathrm{kg} \text { a.i/ha }\end{array}$} & \multicolumn{3}{|c|}{ Samaru } & \multirow[b]{2}{*}{2012} & \multirow{2}{*}{$\begin{array}{l}\text { Mando } \\
2013\end{array}$} & \multirow[b]{2}{*}{ Mean } \\
\hline & & 2012 & 2013 & Mean & & & \\
\hline \multicolumn{8}{|l|}{ Weed Control } \\
\hline S-met + atra & 1.98 & $1856.66 \mathrm{bc}$ & $1800.31 b$ & $1828.49 b c$ & $2373.8 b$ & $2153.18 d$ & $2263.51 b$ \\
\hline S-met + atra & 2.64 & $3291.98 a b$ & $2903.36 b$ & $1910.67 b$ & 3499.1ab & $3382.39 a b$ & $2365.77 b$ \\
\hline Butachlor & 1.5 & $1734.39 c$ & $1856.06 b$ & $1795.22 c$ & 3487.1ab & $3173.69 c d$ & $2330.40 b$ \\
\hline Butachlor & 2.5 & $3284.42 a b$ & $1902.65 b$ & $1922.53 b$ & $3505.5 a b$ & $3215.55 b c$ & $2360.50 \mathrm{~b}$ \\
\hline Hoe Weeding & 3 \&6 WAS & $3303.62 a$ & $2177.51 a$ & $2240.56 a$ & $3704.8 a$ & $3953.89 a$ & $2629.34 a$ \\
\hline Weedy Check & & $760.89 d$ & $928.01 \mathrm{c}$ & $844.30 d$ & $2373.8 b$ & $2246.51 \mathrm{e}$ & $1015.83 \mathrm{c}$ \\
\hline $\begin{array}{l}\text { S.E } \pm \\
\text { Poultry Manure }\end{array}$ & (tons/ha) & 174.890 & 104.913 & 104.157 & 253.155 & 104.093 & 128.146 \\
\hline 0 & & $900.61 \mathrm{c}$ & 872.07c & $886.34 c$ & $1170.9 c$ & $1017.70 c$ & $1094.30 \mathrm{c}$ \\
\hline 4 & & $1880.40 b$ & $2006.65 b$ & $1943.52 b$ & $2350.7 b$ & $2153.95 b$ & $2252.32 b$ \\
\hline 8 & & $3476.83 a$ & $3408.23 a$ & $2441.03 a$ & $3556.2 \mathrm{a}$ & $4015.96 a$ & $3136.06 a$ \\
\hline $\begin{array}{l}\text { S.E } \pm \\
\text { Planting Pattern }\end{array}$ & & 123.200 & 74.201 & 73.941 & 179.029 & 74.002 & 90.183 \\
\hline Single & & $2051.13 b$ & $1151.80 \mathrm{~b}$ & $1101.47 b$ & $2567.3 b$ & 2405.26 & $1436.28 b$ \\
\hline Double & & $3454.09 a$ & $3370.83 a$ & $2412.48 a$ & $3951.2 \mathrm{a}$ & $3819.82 a$ & $2888.51 a$ \\
\hline $\begin{array}{l}\mathrm{S} . \mathrm{E} \pm \\
\text { Interactions }\end{array}$ & & 103.013 & 62.054 & 61.185 & 132.005 & 68.011 & 67.119 \\
\hline $\mathrm{W} * \mathrm{PM}$ & & NS & NS & NS & NS & NS & NS \\
\hline $\mathrm{W} * \mathrm{PP}$ & & NS & NS & NS & NS & NS & NS \\
\hline $\mathrm{P} M * \mathrm{PP}$ & & NS & NS & NS & NS & NS & NS \\
\hline $\mathrm{W} * \mathrm{PM} * \mathrm{PP}$ & & NS & NS & NS & NS & NS & NS \\
\hline
\end{tabular}

Means within a column of any set of treatment group with unlike letter(s) are significantly different at $\mathrm{P} \leq 0.05$ using DMRT 
BAJOPAS Volume 9 Number 2 December, 2016

\section{DISCUSSION}

Influence of Weed Control on Maize Production

The study showed that, hoe weeding at 3 and 6 WAS, application of S-metolachlor + atrazine at $2.64 \mathrm{~kg}$ a.i/ha and butachlor at $2.5 \mathrm{~kg} \mathrm{a.i/ha,} \mathrm{significantly} \mathrm{increased}$ the vegetative and yield attributes of maize than that of the weedy check treated plots as evident by taller maize plants, higher increase in relative growth rate and total grain yield. Better growth and yield parameters obtained for the hoe weeded plots, were statistically similar as those for S-metolachlor + atrazine at $2.64 \mathrm{~kg}$ a.i/ha and butachlor at $2.5 \mathrm{~kg} \mathrm{a.i/ha.} \mathrm{This} \mathrm{showed} \mathrm{that}$ using these combinations of herbicides will give the same result as hoe weeding constantly to keep the maize plot weed free. This is similar to the findings of (Shebayen, 1998; Ishaya, 2004 and Mahadi, 2011) as they stated that weed competition decrease growth and yield of maize plant.

Influence of Poultry Manure on Growth and Yield of Maize

Poultry manure influenced maize growth and yield parameters significantly. This could be attributed to the ability of the manure in supplying nutrients and organic matter to the soil and improving the soil physical conditions. The result showed that increasing rates of poultry manure gave a significant increase in plant height, relative growth rate and maize grain yield across the locations, years and the means. Plants that received $8 \mathrm{t} / \mathrm{ha}$ of poultry manure grew taller than other plants that received $4 \mathrm{t} / \mathrm{ha}$ and the shortest plants that received no application of poultry manure, possibly because more concentrated nutrients or minerals were made readily available and easily absorbable by the receiving plants leading to faster growth and development. This finding is in line with the work of Fagimi and Odebode (2007) who reported increased plant height and number of leaves of pepper resulting from application of poultry manure. Higher total grain yield from plots that received $8 \mathrm{t} / \mathrm{ha}$, than plots that received $4 \mathrm{t} / \mathrm{ha}$ of manure was possible as more nutrient were released which mineralized rapidly for plant uptake and utilization, which favoured the yield increase. This is similar to the findings of DIPA (2006); Fagimi and Odebode, (2007); Gopinath et al., (2008) and Enujeke et al., (2013).

Influence of Poultry Manure on the Soil for Maize Production

The study also showed that poultry manure is a valuable fertilizer and can serve as alternative to chemical fertilizers in the Northern Guinea Savanna Zone of Nigeria. This is in line with the finding of Obi (1991). Plots treated with poultry manure had lower soil temperature compared with plots with non application of poultry manure. Similarly, application of $8 \mathrm{t} / \mathrm{ha}$ of poultry manure in this study increased the moisture content of the soil. This could be related to the improved soil organic matter of plots treated with poultry manure which might have enhanced water retention of the soil and consequently reduced soil temperature of the plots.

\section{REFERENCES}

Ali. A. M. and Sankara S. and Ahmadi. M. (2013). Influence of Planting Pattern and density on the Performance of Maize Hybrid. Int. Journal of Agricultural Biology. 12: 556-560.
Improvement in nutrient status of poultry manure treated plots implies that poultry manure could be use for soil management for sustainable production of maize. In support of this, (Boateng et al., (2006); Tayebeh et al., (2010) reported that Farm Yard Manure (F.Y.M) increased soil P.H and micronutrients of the soil. Mahadi (2011) reported that cow dung manure improved surface P.H. and other nutrients and yield of maize. Aliyu (2002) stated that poultry manure had significant effect on the yield and composition of pepper.

Influence of Planting Pattern on Growth and Yield of Maize

The results from this studies also, showed that planting pattern significantly affect the growth and yield parameters of maize. Plant height was significantly affected by planting pattern, more especially with the double planting pattern, than the single planting pattern and this was possible due to optimum utilization of soil and other environmental resources by the maize plant. The result from this study on grain yield also revealed that grain yield was significantly higher with double planting pattern. This result are supported by Saberali (2007) who verified that number of cobs and number of row per cob are the most important yield components in response to planting pattern in maize. Double planting pattern produced more yield than single pattern. Sangoi (2001) reported that grain yield of maize was significantly higher with double planting pattern than in single row and this was closely related to the environment in light interception during critical period of grain set. The lowest grain yield was obtained at single row pattern, because of lower grain per cob. (Ali et al., 2013) reported that single row significantly affect the main grain yield per plant and 100 seed weight.

\section{CONCLUSION AND RECOMMENDATION}

Based on these findings, application of S-metolachlor + atrazine at $2.64 \mathrm{~kg}$ a.i/ha, butachlor at $2.5 \mathrm{~kg}$ a.i/ha can serve as an alternative to hoe weeding and significantly reduced mean weed population and increased the growth and yield of maize than that of weedy check plots. Use of poultry manure in maize production is recommended as it improved the fertility of the soil thereby increased growth as well as yield of maize. Poultry manure also increased plant height, relative growth rate and maize grain yield. Similarly, double plating pattern (double row per ridge) could also be adopted for effective weed suppression than single planting pattern (single row per ridge) and increased growth and yield of maize.

\section{Conflict of interest}

Authors have declared that no competing interest exist in the paper.

\section{Acknowledgement}

The authors wish to acknowledge the contribution of Ahmadu Bello University, Zaria and College of Agriculture and Animal Science, Mando Kaduna, for providing the facilities for conducting the research.

Aliyu, L. (2002). Analysis of Chemical Composition on Some Organic manures and their Effect in the Yield and Composition of Pepper (Capsium annum L.) Crop Research 23(2): 362-368. 
BAJOPAS Volume 9 Number 2 December, 2016

Anikwe, L.S. Atthor F.M. Sakav, T. (2000) Effect of Different Planting Pattern on Weed Control and Manure Rates on Growth, Yield and Yield. Components of Maize. Indian Agronomy Journal. 42: 265-268.

Bremmer J.M. (1965). Total Nitrogen. In Black, C.A. (Ed). Method of Soil Analysis Part 2. Chemical and Microbiological Properties. American Society of Agronomy, Madison Wisconsin: pp 1149-1179.

Black, C.A. (1965). Method of soil analysis II. Chemical and Microbiological Properties. American society of Agronomy Madison, Wiscensin $1572 \mathrm{P}$.

Boateng, S. A. Zickermann, J. and Kornaharens, M. (2006). Poultry Manure Effect on Growth and Yield of Maize. Crop Science Journal 8(3): 273-282.

Cox, W. J., Hanchar, J. J., Knoblouch, W. A. and Cherney, J. H, (2006). Growth, Yield Quality and Economic of Corn Silage under different Row Spacing, AgronomyJourna/98:163-167.

DIPA (2006). Hand book of Agriculture: Facts and Figures for Farmers, Students and all interested in farming. Directorate of Information and Publication of Agriculture. Indian Council of Agricultural Research, New Delhi. P 435.

Duncan, D.B. (1955). Multiple Range and Multiple F Tests Biometric 11:1-42.

EL-Gizawy, N.K.H.B and Salem, H.M. (2010). Influence of Nitrogen Sources on Yield and its Components of same Maize Varieties. World Journal of Agricultural Science 6(2). 218-223.

Enujeke, E.C., Ojeifo, I.M and Nnaji G.U (2013). Residual Effects of Organic Manure and Inorganic Fertilizer on Maize Grain Weight and some Soil Properties in Asaba area of Nigeria.

FAO (2014). Food and Agriculture Organization of the United Nations Statistics (FAOSTAT) Database Results.

Fagimi, A.A and Odebode, C.A (2007). Effect of Poultry Manure on Pepper Veinal Mottle Virus (PVMV), Yield and Agronomic Parameters of Pepper (Capsicum annum) in Nigeria. East Africa Journal of Science 1(2), 104111.

Gozubenli, H. (2010). Influence of Planting Pattern and Density on The Performance of Maize Hybrid in the Eastern Mediterranean Condition int. Journal of Aricultural Biology 12:556-560.

Gopinath, K.A., Supradip, S., Mina, B.L., Pamde, H., Kundu, S. and Gupta, H.S (2008). Influence of Organic Amendments on Growth, Yield and Quality of Wheat and on Soil Properties during Transsition to Organic Production. Journal of Nutrient Cycling in Agroecosystem, Springer, Netherland,

Hashemi, A.M., Herert, S.J and Putnam, D.H (2005). Yield Response of Corn to Crowding Stress. Agronomy Journal97: 839-846

Idem, N.U.A and Showemimo (2004). Cereal crops of Nigeria: Principles of Production and Utilization Pp337.

Ishaya, D.B (2004). Evaluation of Chemical Weed Control Management Practices on Rainfed Upland Rice (Oryze sativa L.) - Sorghum (Sorghum bicolar L.) Mixture, PhD. Thesis, Department of Agronomy, Ahmadu Bello University, Zaria Nigeria.

Lagoke, S.T.O; Chandra-Singh, D.T.; Adeojonwo, K and Bello, P. (1986). Weed Control in Yam/Maize Mixture in the Nigerian Savanna. A paper presented at the $22^{\text {nd }}$ Annual Conference of the Agricultural Society of Nigeria held at Ahmadu Bello University, Zaria on Sept. 1-3, 1986.

Mahadi, M.A (2011). Effects of Weed Control Methods and Cow Dung Manure on the Performance of Quality Protein Maize (Zea mays L.) in the Northern Guinea Savanna Zone of Nigeria. Ph.D. Thesis, Department of Agronomy, Ahmadu Bello University Zaria, Nigeriua. 102 109pp.
Munamawa M. R., A. S. Goegi and L. Pollak (2006). Seed Quqlity of Maize Inbred Lines with Different Composition and Genetic Backgrounds. Crop Science. 44:542-548.

Obi, J.U. (1991) Maize, its Agronomy, diseases, pests and food values. Optical computer solution Limited. Pp 163165.

Oudejans, J.H. (1991). Agro-pesticide Properties and Functions in Intergrated Crop Protection. United Nations Economic and Social Commission for Asia and the Pacific.

Ogundale, A.O. (2006). On-farm Evaluation of the Economics of Chemical Weed Control in Oxen-Mechanized Maize Production in Nigeria Savannah. Tropical Pest Management. 32(4) Pp. 269-273.

Olsen, J.M., Kristensen, J. Weiner and H.W. Griepengtrog. (1986). Increased Density and Spatial Uniformity Increases Weed Suppression by Spring Wheat (Triticuma estivum) Weed Research 45: 316-321).

Saberali, S.F (2007). Influence of Plant Density and Planting Pattern of Corn on its Growth and Yield Under Competition with common Lambesquaters (Chenopodium album L.). Pajouhesh and Sazandegi 74: $143-152$.

Sangoi, L. (2001). Understanding Plant Density Effect on Maize Growth and Development. An important issue to Maximize Grain Yield. Ciecia Rural, 31: 159-168.

Sarlangue, T., Fermando., H.A., Calvino, P.A and Purcell, L.C (2007). Why do Maize Hybrids Respond Differently to Variation in Planting Pattern. Agronomy. Journal., 99: 984-991.

SAS Institute, (2003). The SAS Users Guide, Version 9.1.3. SAS Institute, Cary, NC.

Sharma and Mitra, (1991). Effect of Different Rates of Application of Organic and Nitrogen Fertilizers in a Maize. Journal of Agricultural Science 111: 413 419.

Sharma, V.K., (2001). Organic Farming as Alternative in India Problems and Prospects, Indian Farming, June, Pp. 23-25.

Sharifai, A. I. (2011). Performance of Extra-early Maize (Zea mays L.) as Influenced by Intra-Row Spacing, Nitrogen and Poultry Manure Rates in Guinea Savanna. A dissertation Submitted to School of Postgraduate Studies, Ahmadu Bello University, Zaria. In fulfillment of Requarement for the Award of Doctor of Philosophy in Agronomy pp 140-146.

Shebayen, Y. J. O (1998). Effects of Row Spacing and Weed Control on Soybean (Glysine max (L.) merril in the Northern Guinea Savanna Zone of Nigeria. Ph.D. Thesis, Department of Agronomy, Ahmadu Bello University Zaria, Nigeriua. 111-123.

Sener, O., Gozubenli, H., Konuskan, $O$ and Kilinc, M (2004). The Effects of Intra-Row Spacing on the Grain Yield and Some Agronomic Characters of Maize (Zea mays L.) Hybrids. Asian Journal of Plant Science 3: 429432

Singh, R.D., Venngopal, K., Gupta, R.K., and Singh. O.B. (2001). Weed Competition Studies and its Control in Sikkim. Indian Journal of Weed Science 19(7); 2933.

Stigter, C.J., Otenb'I, S.B.B., Oluwawasemire, K.O., AL-amin, N.K.N., Kinama, J.K and Onyewuto, L.O.Z (2005b).Recent Answers to Farmland Degradation, Illustrated by Case Studies from African Farming Systems. Annals of the Arid Zone, in print.

Tayebeh, A. Abass, A. and Sayed, A.Z., (2010) Effect of Organic and Inorganic Fertilizers on Grain Yield and Protein Banding Pattern of Wheat. Asia Journal of Crop Science. 4(6): 384-389.

Yahaya, R.A. (1993). Effect of Crop Proportion and Rice thining on the Production of Sorghum Rice mixture M.SC. Thesis, Department of Agronomy, Ahmadu Bello University , Zaria. 86pp 